[PREPRINT]

\title{
Does False Consciousness Necessarily Preclude Moral Blameworthiness?: The Refusal of the Women Anti-Suffragists
}

\author{
Lee Wilson \\ Department of Philosophy, The University of Edinburgh \\ lee.w@ed.ac.uk
}

\begin{abstract}
Social philosophers often invoke the concept of false consciousness in their analyses, referring to a set of evidence-resistant, ignorant attitudes held by otherwise sound epistemic agents, systematically occurring in virtue of, and motivating them to perpetuate, structural oppression. But there is a worry that appealing to the notion in questions of responsibility for the harm suffered by members of oppressed groups is victim-blaming. Individuals under false consciousness allegedly systematically fail the relevant rationality and epistemic conditions due to structural distortions of reasoning or knowledge practices, undermining their status as responsible moral agents.

But attending to the constitutive mechanisms and heterogeneity of false consciousness allows us to see how having it does not eo ipso render someone an inappropriate target of blame. I focus here on the 1889 anti-suffragist manifesto "An Appeal Against Female Suffrage," arguing that its signatories, despite false consciousness, satisfy both conditions for ordinary blameworthiness. I consider three prominent signatories, observing that the irrationality characterisation is unsustainable beyond group-level diagnoses, and that their capacity to respond appropriately to reasons was not compromised. Following recent work on epistemic injustice, I also argue that culpable mechanisms constituted their false consciousness, rendering them blameworthy for the Appeal.
\end{abstract}

Social philosophers and theorists often analyze occasions of 'voluntary victimhood' in terms of false (or ideological) consciousness, referring to a set of evidence-resistant ignorant attitudes held by otherwise sound epistemic agents, systematically occurring in virtue of, and motivating them to perpetuate, structural oppression. ${ }^{1}$ But there is an intuitive worry in general that appealing to the notion of false consciousness in questions of responsibility for the harm suffered by members of oppressed groups amounts to victim-blaming by conceptual fiat (see, e.g., Superson 1993, Cudd 2006, Hay 2013). ${ }^{2}$ That is, where victim-blaming is understood to refer to blaming practices that focus attention inappropriately on victims in accounting for the relevant harms (Harvey 1999; cf. Matthews 2014). ${ }^{3}$ This is because simply using the concept of false consciousness to characterize oppressed agents would, allegedly, not only detract attention from underlying unjust structural conditions but also unduly assume an otherwise absent or diminished moral agency. And this has contributed to the concept's exile from social philosophy and theory in both 'analytic' and 'Continental' circles (see Jaeggi 2009, 82n17). ${ }^{4}$ Considerations of how to theorize about the false consciousness of the oppressed have always avoided the question of moral blameworthiness with some unease (see, e.g., Shelby 2007). The assumption 
behind the 'victim-blaming' intuition, put in Strawsonian terms, is that an individual under false consciousness systematically fails to meet the relevant rationality and epistemic conditions due to structural distortions of reasoning or knowledge practices: such that their status as a responsible moral agent is thereby undermined.

A paradigmatic case of false consciousness can be found in fin-de-siècle Britain, when a hundred and four prominent women put forward the anti-suffragist manifesto "An Appeal Against Female Suffrage." Published in 1889, the Appeal marked a watershed, women-led response to the purported threat of suffragism at the time-an act that, as some suffragists wryly noted, ran counter to not only to the growing need to represent women's interests in legislation but also the very anti-participatory sentiments that the anti-suffragists professed to uphold. There is a general consensus among historians that the Appeal did not simply express the widespread social conservatism of the time but contributed significantly to maintaining this status quo of the parliamentary exclusion of women until their eventual enfranchisement after the First World War (and the profound shifts that it brought to the British workforce).

However, in this case, one might also have the conflicting intuition that it is precisely because of false consciousness, and its attendant epistemic sophistication and lack of coercion, that allows one to legitimately lay part of the blame on such agents. There is a sense that the concept brings to focus crucial but otherwise overlooked agents that are partly responsible for contributing to anti-suffragism. And, as recent historians have noted, narratives that the women of the Appeal were simply uncritical handmaiden in the anti-suffrage cause of men crucially overlooks the unique and thoughtful contribution of the signatories in strategizing and succeeding in "inflecting anti-suffragism with new, more positive emphases designed especially to appeal to female public opinion" in both parliamentary and public debates (Bush 2007, 157; see also Nelson 2004, Delap 2005). The concept of false consciousness provides a constitutive story about how they became a particular type of agent such that we would justifiably attribute the relevant act to them as theirs. False consciousness would thus allow us to see the women antisuffragists as having the same status of agency as their male counterparts (who were themselves largely under the grips of patriarchal ideology), as equally full-fledged members of the moral community. Exempting them as moral agents in limine would not only be unjustly presumptive (the anti-suffragists themselves only expressed opposition to political equality) but also be counter-productive to the emancipatory cause. ${ }^{5}$ Ordinarily, our blaming practices are thought to have a crucial communicative function, addressing agents and appealing to shared reasons for modifying their attitudes or behavior (see, e.g., Calhoun 1989, Houston 1992, Moody-Adams 1994, Fricker 2016a, Mason 2019). In contrast, by theorizing such agents outside the moral community, we preclude ourselves from enlisting them in collective resistance against a shared oppression and to bring about structural change (cf. Shelby 2007, Jugov and Ypi 2019). ${ }^{6}$

So while the intuition of exemption from blameworthiness has been often presumed, I wish to cautiously vindicate the second intuition and allay the worry of victim-blaming. I argue that attending to the constitutive mechanisms and heterogeneity of false consciousness allows us to better see how suffering from it does not eo ipso render an agent an inappropriate target of blame- that is, how one's status as a morally responsible agent is not necessarily undermined by a characterisation of false consciousness. To do this, I take up the women of the Appeal as a historical case study to show how they, even under false consciousness, can satisfy both the rationality and epistemic conditions and thereby qualify for blameworthiness in the ordinary sense. ${ }^{7}$ My main contention here is that too often the broad group-level strokes in painting false 
consciousness as such as irrational, along with focusing on whether a whole category of people can be relevantly aware under situations of oppression, pays insufficient attention to the variety in how the relevant ignorance at the individual level might be nevertheless actively acquired and maintained by the agent as part of their false consciousness.

Important historical work has been done to show how arduous, complex, and often disharmonious it was for women anti-suffragists at the time to formulate and publicise their opposition to the suffrage campaign over the decades (as it also was for the suffragists). As such historians have cautioned, our various understandings of the feminist/anti-feminist distinction today do not easily map onto the suffragist/anti-suffragist distinction, not least because the term 'feminism' was inconsistently deployed and could also be applicable to many anti-suffragists. Indeed, a significant number of anti-suffragists did not see their opposition to suffrage as a maintenance of a patriarchal status quo, but rather as directing women's progress out of the household towards more appropriate social, yet non-political, roles befitting of their gender, e.g. education and healthcare (see, e.g., Delap 2005, Heilmann and Sanders 2006, Crozier-De Rosa 2018). ${ }^{8}$ My approach here is not inconsistent with these important observations, which deserve careful attention in their own right, but my interests are nonetheless primarily philosophical. I attend to the circumstances surrounding the Appeal and any subsequent development only to the extent that they elucidate the rationality and epistemic conditions of blameworthiness in undersigning the Appeal. The narrow focus here on whether we may correctly judge particular signatories as blameworthy for the 1889 Appeal, is thus distinct from the broader and far more complex question about how we should judge them (or women anti-suffragists in general) for hindering or promoting women's interests on the whole-not to mention questions about what would be achieved by blaming them or whether we have the standing to blame them today.

In what follows then, I will first give a sketch of the general concept of false consciousness and its constitutive mechanisms, showing how the two diverging intuitions about the culpability of oppressed agents arise (\$1). I will then attend specifically to the case of the Appeal, observing how its signatories, despite false consciousness, satisfy both rationality and epistemic conditions for ordinary blameworthiness (\$2). ${ }^{9}$ I focus on the details of three prominent women of the Appeal-Louise Creighton, Beatrice Webb, and Mary (Humphry) Ward-arguing that the irrationality characterisation is unsustainable beyond the group-level diagnosis, and that the women of the Appeal's capacity to respond appropriately to reasons was demonstrably not compromised despite them being correctly understood as having false consciousness. Then, drawing on recent work on epistemic injustice and attending to the women's own writings, I argue that there were indeed culpable mechanisms at play in the case of their false consciousness - e.g. testimonial injustice and wilful hermeneutic ignorance-rendering them blameworthy for the Appeal. Lastly, I return to what the case study means for the relationship between the concept of false consciousness and blameworthiness in general, particularly in terms of how such careful historical attention helps refine and delimit our use of the concept as social philosophers or theorists ( $(3)$.

\section{False Consciousness}

False or ideological consciousness is often characterized as a set of attitudes that are epistemically, functionally, and genetically 'false' (Geuss 1981, Meyerson 1991, Shelby 2003). That is, it is a set of 
evidence-resistant ignorant beliefs, that constitute the motivating, and/or (putatively) normative, reasons for an individual to act in ways that maintain a structure of oppression, and that systematically form in virtue of a given structure of oppression. ${ }^{10}$ As a critical concept employed by social philosophers and theorists, false consciousness not only allows us to attend to otherwise neglected oppressive aspects of (i.e. 'problematize') a given social structure that might have initially appeared benign, but, in doing so, orients us towards the possibility of amelioration (see Haslanger 2005, Celikates 2017). It is thus to be understood as the individual, as opposed to structural, side of the same coin as the concept of ideology (see Jaeggi 2009). While the latter concerns the schematisation of resources and agents at the collective level, false consciousness concerns the attitudes of agents at the individual level under these schemas, inasmuch as they occupy a particular node. But its individual-level (or nodal-level) analysis cannot be entirely divorced from the structural. Analysing false consciousness concerns not just how oppressed individuals themselves come to systematically form and maintain certain ignorant beliefs as (putatively) true and normative, given their position within relevant structures, but, further, how beliefs of such content are themselves formed and maintained in these structures. Such analyses would also have to involve how individuals might nevertheless resist the formation or maintenance of such beliefs (sometimes systematically) - i.e. the possibility of emancipatory consciousness.

Broadly speaking, most social philosophers and theorists hold that false consciousness involves an individual (belonging either to oppressor or oppressed groups) mistaking a certain socially objectified understanding of themselves as natural self-understanding (or another functionally similar, authoritative and immutable domain e.g. divine), due to the historical stabilisation of shared pre-existing structures of oppression (see, e.g., Cudd 2006). This involves stabilizing mechanisms (sometimes called 'distortion mechanisms') that occur systematically at both individual and structural levels, resulting in a looping effect in an individual's selfunderstanding given their position in the relevant structure (Haslanger 2011). This looping effect, crucially, involves more than the classification and the classified people. ${ }^{11}$ That is, there are also feedback loops among institutions, knowledge, and experts (Hacking 2006). At the individual level, then, this includes: Nash equilibria, stereotype threat/boost, implicit bias, cognitive failure, preference adaptation, wishful thinking, speech act accommodation, epistemic vice (e.g. arrogance, laziness), and first-order epistemic exclusions (e.g. testimonial injustice). At the structural level: market equilibria, culture industry, consumer production, and second- and thirdorder epistemic exclusions (e.g. hermeneutical injustice or contributory injustice). ${ }^{12}$

Notably, a given form of false consciousness is indexed to the domain of its social structure. That is, the content of the relevant ignorant beliefs are circumscribed by the limits of the schemas and the resources constituting the structure (e.g. a form of false consciousness pertaining to European cisheterosexuality in $19^{\text {th }}$ century Britain would not involve beliefs with content concerning the stellar wind pressure experienced by Proxima Centauri b). And because different social structures can schematize over the same resources and agents (e.g. in overlapping cases of oppression), false consciousness can either be compounded or eroded. In compounding, schemas combine such that the set of ignorant beliefs can gain not only content but further stabilizing mechanisms that reinforce evidence-resistance. In erosion, it could ex bypothesi happen in at least two ways: epistemic friction and radical marginalisation. Epistemic friction occurs when incompatible schemas and stabilizing mechanisms run up against each other and the resultant discordance conduce the possibility of what José Medina calls "metalucidity," which "provides insights in to the functioning of perspectives that makes it possible to 
redraw [one's] cognitive maps, to redescribe [one's] experiences, and to reconceptualize [one's] ways of relating to others" (Medina 2013, 47). In radical marginalisation, according to classical Marxism, an agent (or group of them) is so excluded from social practices that stabilizing mechanisms do not have any grip and there is no feedback loop conducing the internalisation of socially objectified self-understanding. ${ }^{13}$ But, again, both these erosions render emancipatory consciousness only possible and cannot guarantee actualisation-unfortunately, it is perhaps just as common, if not more so, that false consciousness is reinforced by epistemic friction (see Nyhan and Reifler 2010).

Given this analytical framework for false consciousness then, we can now account for how the diverging intuitions of exculpation and culpability arise, considering the diverse mechanisms and different aspects of the heterogeneity of false consciousness. ${ }^{14}$ An oppressed individual's agency and reasons is conceptualized as both constrained and constituted within a structure of oppression, and when the individual-level mechanisms salient for the constitution are culpable, we would regard the agent as blameworthy for the issuing action. This does not mean, however, that false consciousness is, or should be, completely reducible to its constituent mechanisms. ${ }^{15}$ The concept not only plays a crucial regulative role in guiding research in social philosophy within critical projects, emphasizing systematic coordinations of the constituent mechanisms, but adequate normative and epistemological assessments of false consciousness can only be found at the structural level, as ideology critique (Celikates 2017). The mechanisms alone do not guarantee that the beliefs would be ignorant to the extent that they systematically motivate acts of oppression. Explanations appealing to false consciousness are thus 'structural explanations' as Sally Haslanger understands them-that is, they help us understand "the behavior of the individual given their place in a structure" and also understand "the individual as the instance of a type - a type defined by the conditions for existing at that node" (Haslanger 2016).

So the ethical task here of determining whether a specific agent is nonetheless morally responsible would mainly involve the individual-level analysis of the form of false consciousness, attending to the constitutive stabilizing mechanisms salient for the agent, given their position within the relevant structure(s), and the structural-level only insofar as it might restrict or mask rationality, or render ignorance non-culpable. ${ }^{16}$

\section{The Case of the Women Anti-Suffragists}

Before I get to my main argument, it is worth summarizing the argument of the Appeal. It was published in June 1889 in the Nineteenth Century, a mainstream periodical that published debates of leading intellectuals at the time, with a number of unspecified signatories who were largely upper-class women. The Appeal's rejection of suffragism was grounded in the belief that "the limits fixed by the physical constitution of women, and by the fundamental difference which must always exist between their main occupations and those of men" made it such that "the necessary and normal experience of women [...] does not and can never provide them with such materials for sound judgment as are open to men," with respect to parliamentary concerns ("An Appeal Against Female Suffrage"). Effectively, the Appeal argued that women already influence politics in an indirect way that would ensure that their different interests and capacities are accorded due weightage in parliamentary decision-making: suffrage was thus unnecessary and 
counter-productive. What undergirded this was a self-understanding of women of the Appeal as being naturally different in a way that excluded them from the political sphere. According to the Appeal, women's suffrage was both unnecessary and antithetical to their own proper domain of activity, in that direct participation would lead to epistemic and ethical weightlifting (cf. Williams 1995). According to the Appeal, while men were political animals, women were domestic ones.

From this, it is clear how it would be appropriate for us to apply the concept of false consciousness to the women of the Appeal: their belief that women were naturally deficient in political judgment is patently false (epistemic falsity), arising out of the social conservatism of the time (genetic falsity), and it motivated them to undersign a manifesto that buttressed the antisuffragist movement (functional falsity). But despite satisfying the analytic conditions of the concept, I will now go on to show that historical attention to the women of the Appeal's position in fin-de-siècle Britain reveals that the stabilizing mechanisms involved do not undermine their status as morally responsible agents. That is, they would still be blameworthy insofar as the mechanisms do not undermine the rationality and epistemic conditions.

\subsection{The Rationality Condition}

As mentioned at the outset, the concept of false consciousness has often been taken to imply an exempting irrationality on the part of the affected agent. Carol Hay, for example, argues that oppression may damage one's rational capacities permanently and thus disqualify them as a blameworthy agent, citing false consciousness (she calls it 'self-deception') as a "classic" case of such resultant irrationality, wherein "oppressive social systems create incentives for oppressed people to believe certain falsehoods about themselves, contrary to their own evidence" (Hay 2013, 123-124; cf. Superson 1993). It would thus be tempting to think that the women of the Appeal, under conditions of patriarchy, suffered from some sort of collective motivated irrationality, inasmuch as this suggested an inability to respond to reasons to the extent that they would compromise their own interests. After all, the Appeal's success in maintaining the status quo of the parliamentary exclusion of women was not only in its novel, women-friendly packaging of anti-suffragism, but, as suffragist Ray Strachey solemnly recorded in 1928, it "presented [a new argument] to the [anti-suffragist] side. 'Women themselves don't want the vote,' they could now say; unfortunately it was partly true" (Strachey 1978, 285).

But this 'top-down' approach is mereologically suspect: it considers the social-level properties of the women of the Appeal as being instantiated at the individual-level simply in virtue of them being in the group. While the claim of systematic irrationality might be maintained at the level of the signatories as a collective, it is harder to maintain at the individual level of analysis, when we attend to the various mechanisms that formed and maintained the belief in natural incapacity of women for political activity.

As mentioned at the outset, and despite the relative dearth of historical attention on them compared to suffragists, anti-suffragism was neither a fringe nor homogeneous stance among women at the time. While suffragists such as Millicent Fawcett and Margaret Dilke swiftly and acerbically responded in the July issues of the Nineteenth Century and Fortnightly Review, with hundreds undersigned, thousands more signatures came in the August issue of the Nineteenth Century in support of the Appeal. The political equality of women was far from clear as a settled moral fact for the zeitgeist and there were internal disagreements even among those who later 
organised themselves as the Women's National Anti-Suffrage League (1908-1910). Further, much anti-suffragists' sentiments was left unexpressed in the public sphere, not only partly as a "logical extension of their reluctance to take to the stage of parliamentary politics" but also because of "their positive commitment to a paradigm of womanhood characterized by altruistic femininity, devotion to family duties, and inconspicuous public service in the extended domestic setting of local communities," (Bush 2007, 3; see also Heilmann and Sanders 2006, Crozier-De Rosa 2018).

As with all forms of false consciousness, the content of the ignorant beliefs of the women of the Appeal were noticeably bound to the domain of its domestic social structures (although this was only slowly being extended by the influx of women into the labor market). These women were perfectly capable of responding to relevant reasons in other aspects of social life and were well-respected in doing so: Beatrice Webb was a leading sociologist of the cooperative movement and a co-founder of the London School of Economics; Mary Ward was an accomplished novelist who was a prominent advocate for the education of the poor as a means for 'equalisation' in society; Louise Creighton was the co-founder and first president of the bipartisan National Union of Women Workers (NUWW), which coordinated women volunteers throughout Britain.

One might thus instead follow Harriet Taylor and John Stuart Mill in adopting a 'bottomup' mechanical approach to the question of irrationality, guided by a notion of false consciousness (see, e.g., Cudd 2006). In "Enfranchisement of Women," the central question for Taylor and Mill was "why the existence of one-half the species should be merely ancillary to that of the other-why each woman should be a mere appendage to a man, allowed to have no interests of her own, that there may be nothing to compete in her mind with his interests and his pleasure" (Taylor and Mill 1851, 12). They observed that women have been made to "consider as their appropriate virtues" their (at minimum) political dependence on men (ibid., 13). Later, in The Subjection of Women (1869), Mill noted that

All women are brought up from the very earliest years in the belief that their ideal of character is the very opposite to that of men; not self-will, and government by selfcontrol, but submission, and yielding to the control of others. All the moralities tell them that it is the duty of women, and all the current sentimentalities that it is their nature, to live for others; to make complete abnegation of themselves, and to have no life but in their affections. And by their affections are meant the only ones they are allowed to have - those to the men with whom they are connected, or to the children who constitute an additional and indefeasible tie between them and a man. (Mill 1995, 132-133)

But while it might well have been the case that global autonomy was compromised in the declaration of the Appeal (i.e. the women's ability to determine their own ends across the span of their lives), it is less clear that local autonomy is at all compromised for the women of the Appeal (i.e. their capacity to respond appropriately to reasons for the execution of individual acts) since questions about whether one should have, say, potatoes and molasses for supper would not fall under the purview of the relevant form of false consciousness here (McKenna 2005, Oshana 2005). And although some might argue that one's capacity to respond appropriately to reasons may be suitably compromised in under oppression, these arguments have largely been concerned with cases where preference adaptation occurs-that is, when an individual adjusts preferences in light of their frustration (see, e.g., Hay 2013, Cudd 2015). It is 
unclear, however, how the mechanism of preference adaptation would be very salient for the women of the Appeal in their position, given that they were upper and middle class women (none of them were working class). Webb, for example, admits herself that "had [she] been a man, self-respect, family pressure and the public opinion of [her] class would have pushed [her] into a money-making profession; as a mere woman, [she] could carve out a career of disinterested research" (Webb 1929, 355). While these women might have been politically excluded, they were by no means frustrated to the extent that their responsiveness to reasons would be compromised and they nevertheless did have overlapping social concerns with suffragists as was seen in the NUWW (and also in their friendships across partisan lines). ${ }^{17}$

Moreover, it is hard to maintain that the women's local autonomy were so compromised to warrant exculpation, given what we know about the degree of sophistication and strategizing that went into publishing the manifesto. The Appeal was primarily a result of the efforts of coinstigators Ward and Creighton. Creighton herself had expressed, and was compelled by, fears that the increased frequency of franchise attempts in the House of Commons and a sympathetic Prime Minister "[made] it seem likely that Parliament might suddenly pass a bill granting female suffrage" (Louise Creighton to Ida Koch, May 23, 1889). It would not come as a surprise that the editor of the Nineteenth Century, James Knowles, was a known anti-suffragist and saw Ward and Creighton's enthusiasm as a welcome means for his periodical to intervene in the ongoing suffragism debates at such a critical juncture (Bush 2007, 144). But the production and publication of the manifesto was an affair of joint decision-making rather than one of Knowles' sole orchestration. Amongst themselves, moreover, Ward and Creighton were also selfconsciously attempting to distance themselves from the "semi-religious beliefs on the natural and necessary position of women" held by their male counterparts, which they did not "altogether share" (Mary Ward to Louise Creighton, April 18, 1889).

From these considerations, then, we can safely conclude that the capacity to respond to relevant reasons were neither restricted nor masked in any absolute or exemptive way. After all, false consciousness cannot be exemptive simpliciter if we are not willing to also exempt oppressors who suffer it by the same token-there is surely an absurdity in excluding a good portion of the population in limine as morally responsible agents. So while irrationality might actually be the right diagnosis for other forms of false consciousness elsewhere (e.g. those involving preference adaptation), the false consciousness of the women of the Appeal would be better characterized as a matter of having bad premises. That is, the more fruitful approach is not whether they had the capacity to adequately weigh up what was right or wrong in their act of undersigning, but whether they had the awareness of what was right and wrong to begin with.

\subsection{The Epistemic Condition}

It is not uncommon for agents affected by false consciousness to be regarded as exempt from blameworthiness on account of failing to satisfy the epistemic condition. Ann Cudd, for example, thinks that false consciousness renders an agent non-culpably ignorant, noting that "the oppressed may well not understand the oppression they suffer, for it is often a part of their oppression that it is hidden from them under the guises of tradition or divine command or the natural order of things" (Cudd 2006, 198). It is thus also tempting to compare the women of the Appeal with the usual examples found in discussions on culpable ignorance, such as ancient 
slaveholders or sexist U. S. fathers in the 1950s (see, e.g., Benson 2001, G. Rosen 2003, Guerrero 2007, Sher 2017). Much of the debate surrounding these examples concern whether the circumstantial epistemic bad luck that these agents find themselves in is sufficient to exculpate, given that, e.g., "it would have taken a moral genius to see through to the wrongness of chattel slavery" (G. Rosen 2003, 66; cf. Fricker 2007, 98-107). But there are at least two disanalogies here, at individual and structural levels of analyses.

At the individual level, the usual comparisons are almost always cases wherein the agents under analysis are clearly members of the oppressing group-e.g. the "run-of-the-mill" First World, cishet, white, middle-class man in Gideon Rosen's classic case (ibid.) - and not the oppressed: they would not be victims but paradigmatic beneficiaries of epistemic injustice. Perhaps supporting weaker intuitions to exculpate in these cases, the relevant forms of false consciousnesses and corollary stabilizing mechanisms in these would be substantially different from those cases pertaining to members of oppressed groups (e.g. stereotype boost vs stereotype threat).

At the structural level, the applicability of the concept of false consciousness to the women anti-suffragists itself distinguishes this case from these comparisons: where a lack of epistemic friction often thought to characterize cases such as ancient slaveholders, evidence resistance in the case of the anti-suffragists presupposes encounter with dissenting views. In this case, it was clear that there was ample counter-evidence: longstanding suffragist arguments (the centenary of Wollstonecraft's A Vindication of the Rights of Women was just around the corner) and recent shifts in the labor market. ${ }^{18}$ Importantly, the latter meant being faced with the conflict between the social consciousnesses arising out of membership in Victorian society as a politically dependant and that out of membership in the labor market as an economically independentboth of which schematized the same resources. As Dilke replied to the Appeal,

The supporters of woman suffrage do not believe in indirect representation under any circumstances, but least of all when the influx of women into the labour market brings them, whether they will it or no, into competition with those whose interests and capacities are different; it is not the Woman Suffrage Societies that have brought about this great social change. A man is no longer expected, even in well-to-do middle-class society, to support his adult sisters and daughters as well as his wife and infant children. The societies, accepting the new state of things, wish to protect the earning of these women, to teach them self-reliance, to help them in the only way human beings can be efficiently helped-shown how to help themselves.

[...] The rapidly increasing wealth of the middle classes has deprived thousands of women of the necessity for household toil; but education and increased opportunities for intellectual and public work draw these same women, if not in the first, then in the second generation, into busy useful lives, giving satisfaction to themselves and benefit to the community at large. (Dilke 1889)

We see concrete demonstrations of such epistemic friction giving rise to emancipatory consciousness in the public defections of Webb and Creighton to, and in their vocal support for, the suffragist cause between the Appeal's publication and the formation of the Women's National Anti-Suffrage League. In 1906, Creighton announced to the NUWW that she realized that, given the increasing role women were playing in party politics, they needed to have "the responsibility of the vote" (Creighton 1994, 89, 146). ${ }^{19}$ A few days after, Webb wrote a public letter to Fawcett explaining that she now realized that there was a need "to permit this growing 
consciousness among women-that their particular social obligations compel them to claim a share in the conduct of political affairs" by "finding a constitutional channel" (Beatrice Webb to Millicent Fawcett, November 2, 1906). On the contrary, the suffragist responses only served to reinforce Ward's anti-suffragist position, and she intensified her efforts against suffragism in the following years.

The question concerning us, therefore, is whether there were stabilizing mechanisms specific to the women of the Appeal-which were disrupted for Creighton and Webb, or reinforced for Ward-were ones that would have made them culpable for their ignorance, such that judgments that they were blameworthy for undersigning are justified. And from the suffragists' indignant replies, we can gather an affirmative answer: testimonial injustice and wilful bermeneutical ignorance. That is, caused by the prejudices surrounding women and lower classes, the women anti-suffragists not only gave a deflated level of credibility to the suffragists, but also refused to adopt the alternate epistemic resources offered by them. Dilke, for example, laments precisely the neglect of their claims in her reply to the Appeal:

Those who have spoken and written repeatedly on this subject for the last dozen years have a feeling of hesitation and shyness at being obliged to use the same arguments again and again, and to bring but little fresh fuel to feed the furnace of public opinion; but it is only necessary to read through the appeal with care to find that the opponents of further progress have simply burnished up the old weapons and sharpened the timeworn steel. ${ }^{20}$

[...] These ladies take upon themselves to say the time has come to arrest all further progress; ignoring the fact that as the old bonds and fetters fall away from women's limbs new requirements arise, new possibilities open out before them, and careers that but a short quarter of a century ago would have seemed far out of their reach now open before them and seem to call able and well-educated women to fill posts for which their training has fitted them.

[...] Ladies of intellect and social standing can always make their voices heard, can always write to the papers and magazines, can command the sympathy and attention of public men whenever they feel they receive less than justice. But the supporters of woman suffrage aspire to help those other women whose lives are spent in humble toil, whose work is ill paid, whose education has been defective or entirely neglected. (Dilke 1889)

Fawcett was also keen to point out the exclusion, alongside the consequences of the continual lack of enfranchisement of women:

A further consideration of the Nineteenth Century list of names shows that it contains a very large preponderance of ladies to whom the lines of life have fallen in pleasant places. There are very few among them of the women who have had to face the battle of life alone, to earn their living by daily hard work. Women of this class generally feel the injustice of their want of representation. The weight of taxation falls upon them just as if they were men, and they do not see why representation should not go with taxation in their case, simply because their physical strength is less than that of men. (Fawcett 1889)

The ladies in The Nineteenth Century support their case by stating that 'all the principal injustices of the law towards women have been amended by means of the existing constitutional machinery.' They may not know that the law still recognises in a mother no legal rights over her children during the lifetime of her husband. [...] The inequality of 
the divorce law is another well-known instance of the cases in which the existing constitutional machinery has remained placidly content with a state of things unjust to women. The inequalities of the law of intestacy, as regards men and women, are so flagrant as to be almost ludicrous. Existing constitutional machinery has arranged that in almost every case of intestacy the male relatives got the lion's share.

[...] A similar kind of inequality is maintained as regards probate. [...] It is unnecessary to point out that to the whole professional class this necessity of paying probate on what in many cases is the widow's own property, comes at a time when she is impoverished by the death of the chief bread-winner of the family. No such harassing and exacting demands are made upon a man who loses his wife. The assumption of the law is that all their joint property is his only, and he pays no probate on plate, furniture, \&c., which they may have worked for and bought together. "'Women's Suffrage: A Reply") ${ }^{21}$

Fawcett and Dilke's replies expressed feelings of resentment and indignation at how the women of the Appeal seemed to have not only unjustly misrecognized the political status of women but also contributed to normalizing the socio-economic injustices that were being passed over by the systematic underrepresentation of women's concerns in legislation. ${ }^{22}$ But in enacting testimonial injustice, the women of the Appeal not only harmed women by prolonging parliamentary exclusion of their interests, but also their capacity as knowers (Fricker 2007).23 That is, women were excluded in limine as full participants of the epistemic community, where default inclusion is meant to be constitutive of the human condition. Further, as often happens in cases of testimonial injustice, the epistemic harm is compounded in diminished selfconfidence in one's beliefs or own epistemic capacities: Strachey observed a lamentable "phase of discouragement" among suffragists in the aftermath of the Appeal, leading eventually to the militancy of the Suffragettes (Strachey 1978, 285).

There might be a natural concern that the testimonial injustice was itself a product of other exculpatory stabilizing mechanisms constituting false consciousness. Anti-suffragist sentiments, after all, were widespread at the time and there was definitely some measure of hermeneutical injustice. That is, there was some lacuna in the collective conceptual resource: many women were unable to make sense of their own social experience (e.g. the concept of an independent woman). But, at best, this period of overall moral uncertainty involved a situation of a "midway" rather than "maximal" hermeneutical injustice (Fricker 2016b, 167). That is, rather than a complete absence of the relevant conceptual resource, suffragist groups involved "localised or in-group hermeneutical practices that [were] nonetheless not shared across further social space" (ibid., 166). But why these practices did not extend beyond suffragist social spaces into those of the women of the Appeal despite their best efforts, then, might be said to be a case of contributory injustice-wherein "an epistemic agent's willful hermeneutical ignorance [i.e. a willful refusal to acknowledge epistemic tools developed by marginalised groups] in maintaining and utilizing structurally prejudiced hermeneutical resources thwarts a knower's ability to contribute to shared epistemic resources within a given epistemic community by compromising her epistemic agency" (Dotson 2012, 32, emphasis mine; cf. Pohlhaus, Jr. 2012).

It is common to adopt a vice-based approach in cases of epistemic oppression (Fricker, 2007, Medina 2013). So just as the instantiation of the (moral-intellectual) vices of arrogance and laziness may render someone's cultural ignorance culpable, and on that basis they would be blameworthy for an action motivated by culturally ignorant belief, that the women of the Appeal instantiated the vices of testimonial injustice and wilful hermeneutical ignorance should suffice 
to render their ignorance culpable (cf. Mason and Wilson 2017). But, whether conceived of in vice-epistemological terms of otherwise, one might thus conclude from these considerations that the women of the Appeal were culpably ignorant on account of testimonial injustice and wilful hermeneutical ignorance, and accordingly blameworthy for the publication of the Appeal that hindered the suffrage movement.

Nevertheless, there might be lurking worries that the testimonial injustice of the women of the Appeal was a result of a prior state of false consciousness that was non-culpably constituted. Simply having a midway rather than maximal case of hermeneutical injustice, for one, does not guarantee that wilful hermeneutical ignorance was the salient difference-making mechanism for any of the women of the Appeal. Still, if all we seem to require is better evidence to determine which were the salient mechanisms for the women of the Appeal, this would not be problematic for the position set out here, since my claim is simply that the concept of false consciousness would not necessarily rule out blameworthiness. And, attending to Creighton and Webb's explicit reflections about their aforementioned defection, we find that a number of stabilizing mechanisms sustained their beliefs_-none of which they regarded as justificatory and all of which they felt remorse for. Ward, unfortunately, was sadly unmoved even in spite of losing the anti-suffrage cause-but with the relevant stabilizing mechanisms no less discernible.

Creighton's 1906 public announcement of her change in stance was no doubt due at least to her involvement with the NUWW from her presidency in 1895, as a result of which she traveled broadly and "gained a wide knowledge of all kinds of women's questions," coming to eventually feel that "women made great progress, both in speaking and in business capacity" (Creighton 1994, 116). Admitting in her later memoirs that instigating the Appeal "was a mistake on [her] part," and that she had "always hated everything that was concerned with political parties," Creighton noted that "[w] hat was most decisive in leading [her] to change [her] opinion some years afterwards" was her own observation recognition that women needed the vote for their growing participation in "party politics" (Creighton 1994, 89).24 It was also claimed that "her sympathy with the industrial women in the north had led her to see the need of the vote to protect their interests as wage earners" (Covert 2000, 302).

Yet, Fawcett's 1889 reply (to which Creighton herself had provided a public rejoinder a month right after) had already pointed out the need for suffrage to protect working class women, in addition to pointing out the contradiction of the Appeal in holding that women could not form 'sound judgments' on matters of 'constitutional change' and yet nonetheless organized and worked to elect male party candidates (e.g. the Primrose League). Creighton did not obviously seem to pay much attention to these points at the time of the Appeal and recorded that she only realized these for herself after. In this, then, we find that Creighton's testimonial injustice was a result of a wilful hermeneutical ignorance on her part. Rather than heeding Fawcett's reply at the time and during her early tenure as the president of the NUWW, Creighton had refused to acknowledge the legitimacy of the suffragist hermeneutical resources as they were set forth at the time. In Creighton's 1889 rejoinder, she had insistently maintained, against women's participation in parliamentary decision-making, that

If the vote was the privilege of the wise and the educated, many women might justly claim it. But it is the propelling power of a part of the machinery of government which has always belonged to one sex. (Creighton 1889, 351) 
Admittedly, there is some suggestion of the mechanism of stereotype threat in her memoirs. Creighton noted that she was afraid that her recantation would take place too soon after her husband's passing in 1901, such that she would seem to have been against suffrage because of her husband's influence_-even though no one had said this publicly and even though Mandell Creighton himself was not opposed to suffrage and had "left [her] absolutely free to form and express [her] own opinions" (Creighton 1994, 89). But the non-culpable mechanism of stereotype threat here was more relevant for the announcement of her opinions rather than the maintenance of her beliefs about suffrage per se.

Unlike Creighton, Webb notes in her semi-autobiographical volumes that, although she "delayed [her] public recantation for nearly twenty years," she "immediately and resolutely withdrew from that particular controversy" upon Fawcett's "indignant retort" to the Appeal (Webb 1929, 354; cf. 1975, 361). An entry in her manuscript diary, dated only a few days after Fawcett's reply, records her refusal of anti-suffragists' requests of her, given her social and intellectual standing, to respond to Fawcett's 'retort' in the Nineteenth Century:

At present I am anxious to keep out of the controversy. I have as yet accomplished no work which gives me a right to speak as a representative of the class Mrs. Fawcett would enfranchise: celibate women. And to be frank, I am not sure of my ground; I am not certain whether the strong prejudice I have against political life and political methods does not influence my judgement on the question of enfranchising women. (Webb 1929, 354)

Referring to this 'strong prejudice,' Webb later confessed that her "false step" arising out of her being "anti-feminist in feeling [was] easy to explain, though impossible to justify":

Conservative by temperament, and anti-democratic through social environment, I had reacted against the narrow outlook and exasperated tone of some of the pioneers of women's suffrage, with their continuous clamour for the Rights of Women. Also, my dislike of the current parliamentary politics of the Tory and Whig 'ins' and 'outs' seemed a sort of argument against the immersion of women in this atmosphere. But the root of my antifeminism lay in the fact that I had never myself suffered the disabilities assumed to arise from my sex. (Webb 1975, 361, emphasis mine) ${ }^{25}$

Thus, unlike Creighton, Fawcett's 'indignant retort' was what made Webb hesitate about the claim that the 'principal injustices of the law' towards working-class women were indeed 'amended by means of the existing constitutional machinery', as she had undersigned in the Appeal. Although it took some time for her "old prejudice" to eventually "evaporate" altogether, it is noteworthy that it was precisely the suffragists' reactive attitude of indignation (importantly thought to be constitutive of blame) against the signatories that began Webb's eventual epistemic erosion (Webb 1975, 361). ${ }^{26}$ Webb's testimonial injustice against the women of 'exasperated tone' at the time of the Appeal, then, was admittedly not a matter of wilful hermeneutical ignorance. However, she herself confessed later that it had been failure of her own procedural epistemic duties as an "impartial investigator of women's questions," due to the intellectual arrogance she mentioned (ibid., 360).

Unfortunately, unlike Creighton and Webb, Ward passed away less than a year after she planned to write about her own reflections on her participation in the anti-suffrage campaigns (Ward 1919). But when we attend to her response to suffragist replies over the years after the 
Appeal, we see not only a repetition of the 'same' arguments she had set forth with Creighton in the Appeal 'again and again,' but an intensifying thirty-year effort to withhold the extension of suffrage to women-leading eventually to her deflation and defeatism when it was finally won. In a 1910 polemic for The Times, Ward went as far as to describe women as "necessarily ignorant" (Ward 1910). And in her final plea to the House of Lords in January 1918, before the vote, Ward clearly heeded none of the arguments that had won over her other contemporaries: Ward continued to insist that, "because of the conditions of their sex," women were "the less educated, and more excitable, the less skilled, and less responsible elements in [Britain's] population" and indeed that, with the War, "[t]he physical force argument- that physical force is the ultimate sanction of the Parliamentary vote_-stands stronger to-day than ever" (Ward 1918, 48-49, 55). ${ }^{27}$ Presuming that she spoke on behalf of more women than the suffragists, Ward continued to deny not only that women were capable of political participation but that they desired suffrage-in spite of organisations such as the Primrose League or the Suffragettes. After the vote, she wrote defiantly to Creighton:

Well now, thank goodness it is over [...] Now the question is what the women will do with their vote. I can only hope that you and Mrs Fawcett are right and I am wrong. (Mary Ward to Louise Creighton, 14 March 1918)28

What is crucial in interpreting these efforts by Ward is that in her acclaimed novels, she nevertheless very explicitly and penetratingly explores various suffragist positions through her characters: Marcella (1894), which she began writing three years after the Appeal, ends with a balance between the 'liberty' and 'equality' of woman and her social duties; in Delia Blanchflower (1914), the eponymous heroine oscillates convincingly between militant and non-militant forms of suffragism, even prompting an American reviewer unfamiliar with Ward's anti-suffragism to mistake her for a suffragist (Sutton-Ramspeck 2000). Given that, in spite of these aesthetic sympathies, Ward was still politically unsympathetic to the suffrage cause, it would thus not be unsafe to conclude that, like Creighton and Webb, both intellectual arrogance and wilful hermeneutical ignorance were the salient mechanisms lying behind the testimonial injustice that maintained her false consciousness - if not before, then at least definitely in the years after the Appeal.

\section{False Consciousness and Blameworthiness}

Despite its historical and localized nature, the case of the women anti-suffragists provides a useful heuristic for clarifying the possibility and plausibility of blameworthiness under false consciousness more generally across other spheres of oppression and where they overlap (e.g. ablelist, economic, gendered, racial). There are a few reasons why this case study is particularly amenable to this end. First, the reasons of both anti-suffragists and suffragists, as educated and influential women, were well-articulated and documented in fictional and non-fictional works and correspondences. Second, the principled, planned, and protracted efforts of a significant number of the anti-suffragists against suffragism unfortunately echoes among a significant number of women anti-feminists arguing for the political exclusion of women on the basis of natural differences even today. ${ }^{29}$ Third, there is near-universal agreement today that women's suffrage is morally desirable, irrespective of the difficulties that many women might nevertheless 
still face in exercising it. This is particularly important for us as ethicists and social philosophers, since normative and methodological worries about who gets to assess that a given consciousness is 'false', and how, can thus be largely kept at bay for our present inquiries into blameworthiness. Fourth, for better or worse, the dominant discourse of the 1889 Appeal was largely confined to one to two spheres of oppression: gender and economic. This is not to say that other spheres (e.g. colonialism) should be neglected in general, but only that they are not as salient for the particular instances of false consciousness under consideration here. ${ }^{30}$ As such, we are provided a relatively tidy basis upon which social philosophers may extrapolate the present examination of the relation between false consciousness and blameworthiness to more overlapping, complex cases of oppression (e.g. women anti-feminism in the colonies, or racism within queer communities in postcolonial Singapore).

We have seen from the case study that false consciousness does not necessarily exempt one from blameworthiness, where culpable mechanisms (e.g. testimonial injustice) are salient, it may even render one blameworthy. Given the heterogeneity of false consciousness' mechanisms, neither the rationality nor epistemic conditions are necessarily compromised, as the initial intuitive worry set it out to be. An agent's responsiveness to reasons under false consciousness is largely limited to the particular ideology's domain, unless it involves mechanisms such as preference adaptation. An agent may also be culpably ignorant under false consciousness, such as if the relevant evidence-resistant attitudes are sustained by (moral-intellectual) vices where nonculpable mechanisms are not salient in the constitution of those vices. The use of the concept of false consciousness, therefore, is not as morally problematic as some denigrators have suspected—although it should nevertheless be invoked judiciously. ${ }^{31}$

Further, as in the case of Webb, we have also seen that (ordinary) blame, if understood at least in terms of appropriate reactive attitudes (e.g. resentment, indignation) or in terms of addressing the agent and appealing to shared reasons for modifying their attitudes or behavior, may be itself instrumental to the epistemic erosion of a given false consciousness. ${ }^{32}$ In cases where a given false consciousness does not thematize over the reasons to which blame would appeal, the act presents to the relevant agent an instance of epistemic friction. This, as Medina pointed out and we have seen in Webb's awareness of her intellectual prejudices, provides an opportunity for developing meta-lucidity. But, to emphasize, this is only a possibility. For, in other cases perhaps closer to Creighton's (whose own rejoinder brought her national fame as an anti-suffragist), ordinarily blame might seem to only have a backfire effect. What the conditions are for erosive ordinary blame, then, is an important topic for further investigation.

It might be objected that, in the examples given in the case study, Creighton and Webb did not suffer false consciousness - at most Ward did, as evidenced from her persistent beliefs and behavior. However, such an objection involves unnecessarily strict criteria for what false consciousness consists in that is not justified by its role in the critical project. The regulatory concept is only meant to guide research into the contributory elements of structures of oppression and point towards potential sites of amelioration. Both Creighton and Webb fall squarely under the definition of false consciousness: having evidence-resistant beliefs (epistemic falsity), which motivated them to reinforce a particular structure of oppression (functional falsity), and in virtue of which they formed and maintained those very beliefs (genetic falsity). To deny that false consciousness was present, if it were eroded, seems to be dangerously pessimistic about the possibility of emancipatory consciousness forming among the oppressed. Moreover, the shedding of false consciousness for both of them, involving a comprehensive reformation 
of their social self-understanding, took years before the hold that ideological mechanisms had on them eroded and also took great emotional tolls, such as in losing close friendships (as was the case between Creighton and Ward).

Still, the above objection might be coming from a more fundamental worry that if social theorists simply obtain sufficient evidence for the mechanisms behind an agent's psychological makeup and development, the concept of false consciousness itself would thereby be made explanatorily redundant for our blaming practices (apart from functioning as a heuristic for our evidence-gathering). Further, we seem to be moving away from a structural approach into a merely individualist analysis. Under the individualist analysis, it would seem that the concept of false consciousness loses explanatory traction since, as a structural explanation, it characterizes an individual as an instance of a type existing at a structural node. What we would need, then, is not structural analyses — although they may be useful heuristically_but simply better epistemic warrant concerning the individual. Another related worry might be that wilful hermeneutical ignorance cannot be singled out from the nexus of the myriad constitutive individual-level and structural-level mechanisms of false consciousness as the mechanism which specifically resulted in the testimonial injustice of the women of the Appeal. So even if there were culpable mechanisms, the general worry is that they work systematically alongside non-culpable ones in a way that renders them inextricable, insufficient conditions on their own.

But these worries are misplaced and conflates a number of concerns. First, mechanisms such as testimonial injustice, wilful hermeneutical ignorance, or stereotype threat, are structural notions: structural marginalisation is constitutive of them. Second, we need to distinguish between two intersecting, but very different projects here: one that concerns regulating the social research of groups and another that concerns how we, as agents within a moral community, are to respond to fellow agents within it. In the former, we find concerns for the systematicity of mechanisms, culpable and non-culpable, working together as jointly sufficient conditions for ideology. And, as we pointed out earlier, this systematicity is only found when we analyze structures and their ideologies from the perspective of the group. Not all of these mechanisms are relevant in the latter project of our blaming practices: we are only concerned with those mechanisms that were salient for the individual agent in question, such that they would be blamed or exempted accordingly. That preference adaptation might have been a salient mechanism for one individual under a given case of false consciousness, does not mean that it was so for another. Webb, for example, in addition to noting that she did not suffer the 'disabilities assumed to arise from her sex', pointed out that she was in a better socio-economic position than men as a "writer on economic questions" (Webb 1929, 355). To maintain otherwise would be to return to the aforementioned mereological problem, confusing characterisations of entire groups with individuals.

My approach to the question of whether the women anti-suffragists were blameworthy differs from a number of other approaches that have been put forward recently to the question of moral blame in similar cases of systematic social ignorance: forward-oriented responsibility and extended blame. These, it would seem, are promising ways to approach the question of responsibility in cases of false consciousness.

References to Iris Marion Young's "social connection model" of responsibility has been gaining a fair bit of traction recently among some social philosophers as a way to avoid the trappings of attributing fault to an individual for structural effects (Young 2011). That is, such responsibility is "politically assigned rather than discovered" and "potentially grounded in factors 
other than moral desert or causing harm" (Zheng 2018, 4; see also Fricker 2007, Medina 2013, Jugov and Ypi 2019). But while this might be a fruitful way forward in terms of ameliorative task of the critical project, this also notably avoids the notion of blameworthiness entirely, and its attendant moral sentiments in the ordinary cases.

Another notion of blame also gaining traction is grounded in expectations for agents to take responsibility for their actions, independent of whether they committed a fault (see, e.g., Fricker 2016a, Bagnoli 2018, Aragon and Jaggar 2018, Calhoun 2019). Elinor Mason calls this 'extended blame,' inasmuch as we "voluntarily extend our responsibility zone in order to secure the respect and trust of others, and as a way of showing commitment and investment in our relationships" (Mason 2019, 185). It would no doubt seem reasonable to expect the antisuffragists to take responsibility for having undersigned the Appeal. For some, there might be a question as to how much this would be distinct from the former, forward-oriented notion of responsibility (e.g. Fricker 2016a), but in either case it does not involve the full range of moral sentiments relevant to ordinary blameworthiness.

I have argued from a careful consideration of the women of the Appeal that an agent may, in fact, be ordinarily blameworthy under false consciousness. However, to conclude, it should be underscored that despite this, it would be not only intellectually presumptuous but morally pernicious to move straightforwardly from this to the claim that we should blame them or that any act of blaming in similar cases is fully justified. An act of blame does not merely involve the blameworthiness of its recipient but also other crucial aspects such as the aim of blame or one's standing to enact it. The ethics of blame requires that we take into account the justificatory conditions of these other aspects: failing to do so might risk redoubling any harm that might have already satisfied the deterrent purpose of blame or even reinforcing oppressive institutional norms, if blame is performed publicly (cf. Snow 1994, Matthews 2014, Engen 2020). ${ }^{33}$ Until we take all of these into account, we cannot fully assess the justifiability of blaming even in cases like the blameworthy women of the Appeal.

\section{Notes}

1. False consciousness may also be said to affect oppressors, but I will only focused on the oppressed here. It might be said here to be the flip-side of standpoint epistemology, where instead of the conditions of oppression facilitating the development of emancipatory consciousness, they facilitate an entrenchment of ideology.

2. Leaving aside peripheral concerns for now like which normative and epistemological/ methodological standards of critique would be appropriate in employing of the concept of false consciousness (cf. Celikates 2017). That is, what makes a given ideology and false consciousness normatively problematic and how we might be able to figure out that it is so.

3. This is illocutionarily distinct from how victim-blaming is often used as a charge against someone as having problematic motivations (e.g. the 2018 Irish protests over a rape trial in the Central Cork Court where the defence barrister noted that the claimant was "wearing a thong with a lace front").

4. Despite their disagreement over whether oppressed individuals may be blameworthy for acting in ways that contribute to their own oppression, most feminist philosophers are all in 
agreement that false consciousness would exculpate simpliciter (see Superson 1993, Cudd 2006, Hay 2013).

5. These worries have also plagued the debate about the usefulness of the concept of adaptive preferences (cf. Terlazzo 2016).

6. This was thought of as even necessary by classical Marxists and many second-wave feminists.

7. I adopt a broadly Strawsonian approach here, following the likes of Gideon Rosen and Elinor Mason in using 'blameworthiness in the ordinary sense' or 'ordinary blameworthiness' to refer to (see Mason 2019).

8. Such expansion of the domestic also attracted criticisms from within their working-class ranks (see, e.g., Simkins 1909).

9. I exclude the quality of will condition here (see, e.g., Talbert 2013, Arpaly 2015) as the women of the Appeal, as we will see, were clearly well motivated despite being morally mistaken.

10. I focus here on a doxastic mode of false consciousness, since most users largely understand the concept to minimally involve false beliefs. For a survey of modes of false consciousness, see M. Rosen 1996, 70-112.

11. For criticisms of this caricature, see, e.g., Celikates 2017.

12. See Adorno and Horkheimer 2016, Žižek 2008, M. Rosen 1996, Cudd 2006, Haslanger 2011, Dotson 2014, Langton 2015, Stanley 2015, Mallon 2016, Celikates 2017, Mason and Wilson 2017.

13. See, for example, Marx's comments on the proletariat, a class have nothing to lose but their "radical chains," as the possibility of German emancipation in the Introduction to the Critique of Hegel's Philosophy of Right (Marx 1844, 186).

14. As those working on the concept of ideology such as Jon Elster, Michel Pêcheux, and Michael Rosen have warned, there must be some account of the mechanisms bridging of social-level properties and individual-level properties if a theory of ideology is to avoid mereological or "Münchhausen” problems (Elster 1985, Pêcheux 1994, Rosen 1996).

15. By 'individual-level analysis', I do not mean an 'individualist analysis', wherein the structural context is occluded (see Garfinkel 1981, Haslanger 2016).

16. Here, it might be useful to note the analogy of these tasks with the regulative and constitutive operations of reason for Kant, as laid out in the Third Critique (5: 401-404).

17. Further, given Mill's account, it seems odd to speak of adjusting preferences if was something one was brought up with.

18. Many suffragists, however, did not necessarily share the so-called 'liberal feminism' of Wollstonecraft, which argued for the cause of women from individual rights rather than social role ('social feminism'). To note, the passing references to 'feminism' here is meant only in the broad sense of the promotion of equal consideration of women's interests.

19. Creighton's memoirs seems to suggest that this refers to a conference in 1912, but Fawcett's letter to the editor of The Times in 1906 mentions Creighton's change in her views in October 1906, which also would be consistent with her Women in Council obituary (Millicent Fawcett to the editor of The Times, 5 November 1906; "Louise Creighton Obituary," Women in Council Newsletter, May 1936; cf. Creighton 1994, 172n30; Covert 2000, 368n32; Bush 2007, 162n61). 
20. To be fair, while Dilke was right to note that the underlying arguments had not changed despite the new rhetoric, she missed out on Strachey's observation of the new (though problematic) argument that women themselves did not desire the vote.

21. Although the publication's author was unspecified, this is commonly attributed to Fawcett by historians given her writing style (Nelson 2004, Bush 2007).

22. There might be a concern that the salient brand of oppression here would actually be class rather than gender, such that our concern here should not longer be a case of the false consciousness of the oppressed but rather that of members of the oppressing group. But as we observed earlier, given that social structures overlap, while gender oppression is foregrounded in the general notion of suffragism, there is a need to appreciate the overlapping nature of oppression and the heterogeneity of the stabilizing mechanisms of false consciousness. Moreover, the undersigned of the Appeal were, as Fawcett observed above, also partly composed of women who would be directly affected by the success or failure of the suffragism. For an example of working-class anti-suffragism, see Simkins 1909.

23. That is, whether the credibility deficit is understood non-distributively or otherwise (see Medina 2013, Coady 2017).

24. She also notes that she thought the Suffragettes "needed to be steadied by responsibility" given their "wild performances" (Creighton 1994, 146).

25. This appears almost verbatim Webb's earlier volume My Apprenticeship (1929), with a removed note about how her anti-feminist feeling was a part-reaction to "[her] father's overvaluation of women relatively to men," and another about "a luncheon given by an American lady to American suffragists (who had not given [Webb] a cigarette to sooth [her] distaste for the perpetual reiteration of the rights of women) venting this irritation by declaring provocatively_- I have never met a man, however inferior, whom I do not consider to be my superior!"” (Webb 1929, 355).

26. For those who think resentment or indignation are essential to blame, see, e.g., Strawson 1962, G. Rosen 2015.

27. Ward even reached towards bold, conspiratorial reasoning towards the end of her plea: "I do not doubt its sincerity on the lips of many good men for a moment. But the real motive power bebind the clauses, so far as the House of Commons, and political parties are concerned, has been simply political calculation" (Ward 1918, 52).

28. Ward's initially close friendship with Creighton was now very strained at this point. In November 1912, she was removed from the NUWW and in 1917, writes to Creighton, "I thought of telling you something of what your old friends have gone through in the last four years and how changed our life has been. But on the whole it seemed better notSilence is best" (Mary Ward to Louise Creighton, 12 September 1917).

29. See Coulter 2007, Bloomfield 2016.

30. This has been a longstanding problem with suffragism and suffragist historiography and has only been more recently attended to (Delap et al. 2006, Crozier-De Rosa 2018): e.g. Fawcett's outrage that Maori women, following their enfranchisement, were in a superior position to English women (Adams 2014, 118); the hitherto overlooked contributions of Sophia Duleep Singh in the suffragette movement (Anand 2015); and the New Woman novel as emerging from the context of imperial South Africa (Free 2016 cf. Crozier-De Rosa 2010).

31. Without first settling the normative and epistemological parameters, for example, the use of the concept may be susceptible to paternalistic misuse (Cunningham 1987). 
32. Of course, this does not necessarily mean that Fawcett herself was engaging in blame in her retort to Webb.

33. See Coates 2020 for a survey of these other aspects of the ethics of blame in general.

\section{References}

Adams, Jad. 2014. Women and the vote: A world history. Oxford: Oxford University Press.

Adorno, Theodor W. and Max Horkheimer. 2016. Dialectic of enlightenment. Translated by John Cumming. London and New York: Verso.

An Appeal Against Female Suffrage. 1889. Nineteenth Century 25 (June): 781-788.

Anand, Anita. 2015. Sophia: Princess, suffragette, revolutionary. London: Bloomsbury.

Aragon, Corwin, and Alison M. Jaggar. 2018. Agency, complicity, and the responsibility to resist structural injustice. Journal of Social Philosophy 49 (3): 439-460.

Arpaly, Nomy. 2015. Huckleberry Finn revisited: Inverse akrasia and moral ignorance. In The nature of moral responsibility: New essays, ed. Randolph Clarke, Michael McKenna, and Angela M. Smith. Oxford: Oxford University Press.

Bagnoli, Carla. 2018. "Claiming responsibility for action under duress." Ethical Theory and Moral Practice 21 (4): 851-868.

Benson, Paul. Culture and responsibility: A reply to Moody-Adams. Journal of Social Philosophy 32 (4): 610-620.

Bloomfield, Janet. 2016. Three reasons \#whywomenshouldnotvote. Judgybitch. http:// judgybitch.com/2016/02/08/three-reasons-whywomenshouldnotvote (accessed February 21, 2019).

Bush, Julia. 2007. Women against the vote: Female anti-suffragism in Britain. Oxford and New York: Oxford University Press.

Calhoun, Cheshire. 1989. Responsibility and reproach. Ethics 99 (2): 389-406.

- 2019. Responsibilities and taking on responsibility. Proceedings of the Aristotelian Society 129 (3): 4-23.

Celikates, Robin. 2017. Epistemische Ungerechtigkeit, Loopingeffekte und Ideologiekritik. Eine sozial-philosophische Perspektive. WestEnd: Neue Zeitschrift für Sozialforschung 2: 53-72.

Coady, David. 2017. Epistemic injustice as distributive injustice. In The Routledge handbook of epistemic injustice, ed. Ian James Kidd, José Medina, and Gaile Pohlhaus, Jr.. London and New York: Routledge.

Coates, D. Justin 2020. The ethics of blame: A primer. In The ethics of belief and beyond: understanding mental normativity, ed. Gerhard Ernst, Lisa Marani, and Sebastian Schmidt. Abington: Routledge.

Coulter, Ann. 2007. I am woman, hear me bore. Townhall. https://townhall.com/columnists/ anncoulter/2007/01/24/i-am-woman,-hear-me-bore-n935419 (accessed February 21, 2019).

Covert, James T. 2000. A Victorian marriage: Mandell and Louise Creighton. London and New York: Hambledon and London.

Creighton, Louise. Louise Creighton to Ida Koch, May 23, 1889.

- 1889. The appeal against female suffrage: A rejoinder [to Fawcett and Dilke in July], Nineteenth Century 26 (August): 347-354.

-1994. Memoir of a Victorian woman: Reflections of Louise Creighton, 1850-1936, ed. James Thayne Covert. Bloomington and Indianapolis: Indiana University Press.

Crozier-De Rosa, Sharon. 2010. The New Woman at home and abroad: Fiction, female identity and the British Empire." In Europe's expansions and contractions: Proceedings of the XVIIth Biennial Conference of the Australasian Association of European Historians, ed. Evan Smith. Adelaide: Australian Humanities Press.

. 2018. Shame and the anti-feminist backlash: Britain, Ireland, and Australia, 1890-1920. New York: Routledge. 
Cudd, Ann E. 2006. Analyzing oppression. Oxford and New York: Oxford University Press.

2015. Adaptations to oppression: Preference, autonomy, and resistance. In Personal autonomy and social oppression: Philosophical perspectives, ed. Marina A. L. Oshana. New York and London: Routledge.

Cunningham, Frank. 1987. Democratic theory and socialism. Cambridge: Cambridge University Press.

Delap, Lucy. 2005. Feminist and anti-feminist encounters in Edwardian Britain. Historical Research 78 (201): 377-399.

Delap, Lucy, Louise Ryan, and Teresa Zackodinik. 2006. Self-determination, race, and empire: feminist nationalists in Britain, Ireland and the United States, 1830s to World War One." Women's Studies International Forum 29: 241-254.

Dilke, Mary Margaret. 1889. The appeal against female suffrage: A reply. II. Nineteenth Century 26 (July): 97-103.

Dotson, Kristie. 2012. A cautionary tale: On limiting epistemic oppression. Frontiers: A Journal of Women Studies 33 (1): 24-47.

- 2014. Conceptualizing epistemic oppression. Social Epistemology 28 (2): 115-138.

Elster, Jon. 1985. Making sense of Marx. Paris: Cambridge University Press.

Engen, Andy. 2020. Punishing the oppressed and the standing to blame. Res Philosophica 97 (2): 271-295.

Fawcett, Millicent G. 1889. The appeal against female suffrage: A reply. I. Nineteenth Century 26 (July): 86-96.

1906. Millicent Fawcett to the editor of The Times, November 5.

Free, Melissa. 2016. British women wanted: Gender, genre, and South African settlement. The Oxford handbook of Victorian literary culture, ed. Juliet John. Oxford: Oxford University Press.

Fricker, Miranda. 2007. Epistemic injustice: Power and the ethics of knowing. Oxford and New York: Oxford University Press.

- 2016a. Fault and no-fault responsibility for implicit prejudice-A space for epistemic agent-regret. In The epistemic life of groups: Essays in the epistemology of collectives, ed. Michael Brady and Miranda Fricker. Oxford: Oxford University Press.

- 2016b. Epistemic injustice and the preservation of ignorance. In The epistemic dimensions of ignorance, ed. Rik Peels and Martijn Blaauw. Cambridge: Cambridge University Press.

Garfinkel, Alan. 1981. Forms of explanation: Rethinking the questions in social theory. New Haven and London: Yale University Press.

Geuss, Raymond. 1981. The idea of a critical theory: Habermas and the Frankfurt school. Cambridge: Cambridge University Press.

Guerrero, Alexander A. 2007. Don't know, don't kill: Moral ignorance, culpability, and caution. Philosophical Studies 136 (1): 59-97.

Hacking, Ian. 1999. The social construction of what? Cambridge, MA, and London: Harvard University Press.

- 2006. Kinds of people: Moving targets. Proceedings of the British Academy 151: 285-318.

Harvey, Jean. 1999. Civilized oppression. Lanham: Rowman \& Littlefield Publishers, Inc.

- 2015. Civilized oppression and moral relations: Victims, fallibility, and the moral community, ed.

Antonio Calcagno. New York: Palgrave Macmillan.

Haslanger, Sally. 2005. What are we talking about? The semantics and politics of social kinds. Hypatia 20 (4): 10-26.

- 2011. Ideology, generics, and common ground. In Feminist metaphysics: Explorations in the ontology of sex, gender and the self, ed. Charlotte Witt. Dordrecht and London: Springer.

- 2016. What is a (social) structural explanation? Philosophical Studies 173 (1): 113-30.

Hay, Carol. 2013. Kantianism, liberalism, and feminism: Resisting oppression. London: Palgrave Macmillan.

Heilmann, Ann and Valerie Sanders. 2006. The rebel, the lady, and the 'anti': Femininity, antifeminism, and the Victorian woman writer. Women's Studies International Forum 29 (3): 289-300.

Houston, Barbara. 1992. In praise of blame. Hypatia 7 (4): 128-147. 
Jaeggi, Rahel. 2009. Re-thinking ideology. Translated by Eva Engels. In New waves in political philosophy, ed. Boudewijn Paul de Bruin \& Christopher F. Zurn. New York: Palgrave-Macmillan. Jugov, Tamara and Lea Ypi. 2019. Structural injustice, epistemic opacity, and the responsibilities of the oppressed. Journal of Social Philosophy 50 (1): 7-27.

Kant, Immanuel. 2002. Critique of the power of judgment. Translated by Paul Guyer and Eric Matthews. Cambridge: Cambridge University Press.

Langton, Rae. 2015. How to get a norm from a speech act. The Amberst Lecture in Philosophy 10: 133.

Louise Creighton Obituary. Women in Council Newsletter, May 1936.

Mallon, Ron. 2016. The construction of social kinds. Oxford: Oxford University Press.

Marx, Karl. 1844. Contribution to the critique of Hegel's philosophy of law. In Karl Marx \& Frederick Engels: Collected works, volume 3, Marx and Engels, 1843-1844, 175-87. London: Lawrence and Wishart, 1975.

Mason, Elinor. 2019. Ways to be blameworthy: Rightness, wrongness, and responsibility. Oxford: Oxford University Press.

Mason, Elinor and Alan T. Wilson. 2017. Vice, blameworthiness, and cultural ignorance. In Responsibility: The epistemic condition, ed. Philip Robichaud and Jan Willem Wieland. Oxford: Oxford University Press.

Matthews, Steve. 2014. The imprudence of the vulnerable. In Ethical Theory and Moral Practice 17 (4): 791-805.

Medina, José. 2013. The epistemology of resistance: Gender and racial oppression, epistemic injustice, and resistant imaginations. New York, Oxford University Press.

Meyerson, Denise. 1991. False consciousness. Oxford: Clarendon Press.

McKenna, Michael. 2005. The relationship between autonomous and morally responsible agency. In Personal autonomy: New essays on personal autonomy and its role in contemporary moral philosophy, ed. James Stacey Taylor. Cambridge: Cambridge University Press.

Mill, John Stuart. 1995. The subjection of women. In On liberty, with the subjection of women and chapters on socialism. Cambridge: Cambridge University Press, 1995.

Moody-Adams, Michele. 1994. Culture, responsibility, and affected ignorance. Ethics 104 (2): 291-309.

Nelson, Carolyn Christensen. 2004. Literature of the women's suffrage campaign in England. Peterborough, Ontario: Broadview Press.

Nyhan, Brendan and Jason Reifler. 2010. When corrections fail: The persistence of political misperceptions. Political Behavior 32 (2): 303-330.

Oshana, Marina A. L. 2005. Autonomy and free agency. In Personal autonomy: New essays on personal autonomy and its role in contemporary moral philosophy, ed. James Stacey Taylor. Cambridge: Cambridge University Press.

Pêcheux, Michel. 1982. Language, semantics and ideology: Stating the obvious. Translated by Harbans Nagpal. London and Basingstoke: The MacMillan Press Ltd.

Pohlhaus Jr., Gaile. 2012. Relational knowing and epistemic injustice: Toward a theory of willful hermeneutical ignorance. Hypatia 27(4): 715-735.

Rosen, Gideon. 2003. Culpability and ignorance. Proceedings of the Aristotelian Society, New Series, 103: 61-84.

- 2015. The alethic conception of moral responsibility. In The nature of moral responsibility: New essays, edited Randolph Clarke, Michael McKenna, and Angela M. Smith. New York: Oxford University Press.

Rosen, Michael. 1996. On voluntary servitude: False consciousness and the theory of ideology. Cambridge: Polity Press.

Shelby, Tommie. 2003. Ideology, racism, and critical social theory. The Philosophical Forum 34 (2): $153-88$.

. 2007. Justice, deviance, and the dark ghetto. Philosophy and Public Affairs 35 (2): 126-160.

Sher, George. 2017. Blame and moral ignorance. In Responsibility: The epistemic condition, ed. Philip Robichaud and Jan Willem Wieland. Oxford: Oxford University Press. 
Simkins, Maud Ellen. 1909. The working woman's plea for exemption from political responsibility. In An Englishwoman's home, 3-28. London: Sampson Low, Marston \& Co. Limited.

Snow, Nancy E. 1994. Self-blame and blame of rape victims. Public Affairs Quarterly 8 (4): 377393.

Strachey, Ray. 1978. The cause: A short history of the women's movement in Great Britain. London: Virago.

Strawson, P. F. 1962. Freedom and resentment. Proceedings from the British Academy 48: 1-25.

Superson, Anita M., 1993. Right-wing women: causes, choices, and blaming the victim. Journal of Social Philosophy 24 (3): 40-61.

Sutton-Rampseck, Beth. 2000. Shot out of the canon: Mary Ward and the claims of the conflicting feminisms. In Victorian women writers and the woman question, ed. Nicola Diane Thompson. Cambridge: Cambridge University Press.

Talbert, Matthew. 2013. Unwitting wrongdoers and the role of moral disagreement in blame. In Oxford studies in agency and responsibility, vol. 1, ed. David Shoemaker. Oxford: Oxford University Press.

Terlazzo, Rosa. 2016. Conceptualizing adaptive preferences respectfully: An indirectly substantive account. The Journal of Political Philosophy 24 (2): 206-226.

Taylor, Harriet and John Stuart Mill. 1851. Enfranchisement of women. Westminster Review 55 (July): 289-311.

Ward, Mary Augusta. 1889. Mary Ward to Louise Creighton, April 18.

- 1910. The eve of the bill. The Times, July 11, 1910.

- 1917. Mary Ward to Louise Creighton, September 12.

- 1918. Let women say! An appeal to the House of Lords. Nineteenth Century and After 83 (January): 47-59.

1918. Mary Ward to Louise Creighton, March 14.

1919. A writer's recollections. London: W. Collins Sons and Co. Ltd.

Webb, Beatrice. 1906. Beatrice Webb to Millicent Fawcett, November 2.

1929. My apprenticeship. London, New York, and Toronto: Longmans, Green and Co.

1975. Our partnership, ed. Barbara Drake and Margaret I. Cole. Cambridge: Cambridge University Press.

Williams, Bernard. 1995. Replies. In World, mind, and ethics: Essays on the ethical philosophy of Bernard Williams, ed. J. E. J. Altham and Ross Harrison, 185-224. New York: Cambridge University Press.

Women's suffrage: A reply. 1889. Fortnightly Review 52 (July): 123-131.

Young, Iris Marion. 2011. Responsibility for justice. New York: Oxford University Press.

Zheng, Robin. 2018. What is my role in changing the system? A new model of responsibility for structural injustice. Ethical Theory and Moral Practice 21 (4): 869-885.

Žižek, Slavoj. 2008. The sublime object of ideology. London and New York: Verso. 